\title{
Progressive and Regressive Algae of the Genus Navicula Bory (Bacillariophyta) of Water Bodies of the Chirchik River Basin (Uzbekistan) and Protecshion
}

\author{
Alimjanova Kholiskhon Alimjanovna ${ }^{1, *}$, Turabaev Akmal Normuminovich ${ }^{2}$, \\ Shaiimculova Minabar Abduvaiitovna ${ }^{3}$, Rajabova Mamura Saparovna ${ }^{4}$, \\ Soatov Giyosiddin Turdiyevich ${ }^{4}$ \\ ${ }^{1}$ Institute of Botany of the Academy of Sciences of the Republic of Uzbekistan, Tashkent, Uzbekistan \\ ${ }^{2}$ Department of Ecologic Montabitoring, Faculty of Ecology, National University of Uzbekistan, Tashkent, Uzbekistan \\ ${ }^{3}$ Department of Theory and Primary Education, Faculty of Pedagogy, Psychology and Physical Education, Osh State University, Osh, \\ Kyrgyzstan \\ ${ }^{4}$ Department of Ecology, Faculty of Ecology, National University of Uzbekistan, Tashkent, Uzbekistan
}

\section{Email address:}

alimjanovakh@gmail.com (A. Kh. Alimjanovna),Akmal_tura1973@mail.ru (T. A. Normuminovich),

sh-minabar62@mail.ru (S. M. Abduvaiitovna),mamura480@gmail.com (R. M. Saparovna),

rakhmatullaev_physiology@yahoo.com (S. G. Turdiyevich)

${ }^{*}$ Corresponding author

\section{To cite this article:}

Alimjanova Kholiskhon Alimjanovna, Turabaev Akmal Normuminovich, Shaiimculova Minabar Abduvaiitovna, Rajabova Mamura Saparovna, Soatov Giyosiddin Turdiyevich. Progressive and Regressive Algae of the Genus Navicula Bory (Bacillariophyta) of Water Bodies of the Chirchik River Basin (Uzbekistan) and Protecshion. American Journal of BioScience. Vol. 9, No. 1, 2021, pp. 10-16. doi: 10.11648/j.ajbio.20210901.12

Received: November 30, 2020; Accepted: December 17, 2020; Published: January 18, 2021

\begin{abstract}
In the article, the authors present for the first time the progressive and regressing algae of the genus Navicula Bory (Bacillariophyta) in the water bodies of the Chirchik River basin. The research was carried out during 2005-2012, 20182020 yy. with the National Universities of Uzbekistan and the Institutes and Botany of the Academy of Sciences of the Republic of Uzbekistan. 122 species and varieties of algae of the genus Navicula Bory have been identified. Among them, new species for water bodies, saprobic indicators were noted, the seasonality of algae was studied. The main new ideas in the article are as follows: among the algae found, it is progressive algae 6. They are found "often", "very often", "in mass or mass" in one field of view of the objective, their frequency of occurrence is equal to 5, 7,9 points and is considered a resistant species in various environmental conditions, being a promising algae with full life. 96 - less progressive algae, occurs "often", "rarely", the occurrence is equal to 5, 3 points and is less resistant and less promising algae with a sex life. 20 species and varieties are regressing algae, in water bodies it meets only "units" (single), the frequency of occurrence is equal to 1 (one) point and is considered unstable algae of the investigated water bodies, in the future, there is a threat to safety and Not Live! (No Life!) Needs protection. It was proposed to include in the next issue of the "Red Book" of the Institute of Botany of the Academy of Sciences of the Republic of Uzbekistan, as well as to accept and include in the list of protected microorganisms water bodies of Uzbekistan under the Committee for Ecology and Nature Protection of the Republic of Uzbekistan.
\end{abstract}

Keywords: Bacillariophyta: Genus Navicula Bory, Progressive, Less Progressive, Regressive, Navicular Algae, Protection, Recommendations 


\section{Introduction}

\subsection{Relevance of the Topic}

At present, abiotic, biotic and anthropogenic environmental [1, 15, 24] factors have a fairly wide impact and significantly affect the growth and development of microorganisms, including microalgae, living in various water bodies. There are some factors that help the development of aquatic microorganisms, and there are some factors that threaten, from which microalgae become on the verge of disappearance or disappearing microalgae. All over the water bodies of the world, including the CIS water bodies, more than 20 percent is occupied by the genus Navicula Bory $[18,19]$. Among the reservoirs of Uzbekistan, the reservoirs of the Chirchik River basin in terms of biological diversity, diatom algae (Bacillariophyta) prevail [2]. Among diatoms, algal species of the genus Navicula Bory are considered rich in biodiversity $[5,13,16,23]$. We know that algae are producers and form a food base for aquatic and for aquatic hydrobiont organisms. Also, there are oxygen sources for their life. Participates in self-purification and bioindication of water quality in reservoirs. They also participate in biological wastewater treatment. The biological diversity of algae, rational use and their protection is currently an urgent problem. In this regard, the topic "Progressing and regressing microalgae of the genus Navicula Bory..." is considered a very relevant idea, which raises these issues for the first time in Uzbekistan and meets one of the main tasks of scientific research of the global problem "Man and the Biosphere".

There is no information about these topics in the previous literature $[6-8,13,17,20-22]$. The topic is being studied for the first time by us.

\subsection{Objective of the Research}

To study the progressive and regressing microalgae of the genus Navicula Bory in water bodies of the Chirchik river basin

\subsection{Research Objectives}

1) Collection of materials from various water bodies of the Chirchik river basin and their determination of the species composition;

2) Taxonomic analyzes of microalgae and their distribution in water bodies;

3) Progressing microalgae and their prospects;

4) Regressing microalgae and their perspectives;

5) Development of recommendations for protection "On the verge of endangered species of microalgae of the genus Navicula Bory" (Bacillariophyta).

\section{Materials and Research Methods}

The collection of materials was carried [11] out from 2006 to 2012, and continued until 2018-2020 at the Department of Ecology of the National University of Uzbekistan and together with the "Algological collection" of the Institute of
Botany of the Academy of Sciences of the Republic of Uzbekistan. A sample was collected from various reservoirs of the Chirchik River basin using algological and hydrobiological research methods. To determine the species composition of the genus Navicyla Bory, a Carl Zeiss light microscope was used. The species composition was determined according to the key to freshwater algae of the USSR (1951), issue 4 Diatoms (Bacillariophyta) [12, 14, 28]. The number of algae was assessed using a relative frequency scale (1-9) after recalculation per 100 fields of view in accordance with the categories (first and second) of cell size [25]. To store the database - a personal computer hp Samsung Word 10 program.

\section{Results and Discussion}

\subsection{Results}

As a result, for a sufficient time, algological materials were collected and processed, the species composition of microalgae was determined, as a result, a list of progressive and regressing microalgae in water bodies of the Chirchik river basin was compiled. The collected algological samples are stored in the algological collection of the Institute of Botany of the Academy of Sciences of the Republic of Uzbekistan, partly at the Department of Ecology of the National University of Uzbekistan, and the list of progressive and regressing microalgae of the genus Navicula Bory is stored in the "Database of Algological Collections" and "TASH" of the Institute of Botany of the Academy of Sciences of the Republic of Uzbekistan.

The collection materials were used during educational processes at the Department of Ecology of the Ecologycal Faculty and at the Department of Botany of the Biological Faculty of the National University of Uzbekistan and of the Osh State University of Kyrgyzstan.

122 species and varieties of microalgae of the genus Navicula Bory have been identified for the water bodies of the basin.

\subsection{Discussion Progressive and Regressive Algae}

Among the species of the genus Navicula Bory, N.constantini (Skv.) Skabitch., N.cryptocephala Kuetz N.cryptocephala var.veneta Grun., N.lanceolata var.cymbula (Donk.) Cl., N.lanceolata var.tenella A. S., N.menisculus var.meniscus (Schum.) Hust. are the progressive species of water bodies in the Chirchik River basin. They develop abundantly mainly in summer and autumn, the frequency of occurrence is «often», «very often», and «the mass» is from 5 to 9 points (table 1). These algae differ from others, more resistant to survival in a given environment, high growth rates and have a practical nutritional value of food among aquatic organisms.

They are distributed over water bodies in this way. Among the progressive microalgae, all 6 species are found in the right-bank irrigation system, mainly - "often", "in mass" quantities; 4 species are found in rice fields - «often»; 3 - in 
the Chirchik river - «often» and in «bulk» or "the mass"; 2 for mountain reservoirs, reservoir and left-bank irrigation system - "rarely" and "often"; and in fish ponds there is only 1 species; biological ponds - not marked. The high frequency of occurrence of algae is from 5 to 9 points. Two species are indicator algae and two species were first discovered for the basin (table 1).

Table 1. Progressive algal species of the genus Navicula Bory of water bodies of the Chirchik river basin.

\begin{tabular}{|c|c|c|c|c|c|}
\hline \multirow{2}{*}{$\begin{array}{l}\text { Department name Bacillariophyta - Diatomaceous algae } \\
\text { Class Pennatae, Order Raphinales, Suborder Diraphineae, Family } \\
\text { Naviculaceae West, Genus Navicula Bory }\end{array}$} & \multirow{2}{*}{$\begin{array}{l}\text { Saprobity } \\
\text { Algae saprobity, S }\end{array}$} & \multicolumn{4}{|c|}{ Frequency of occurrence of algae by seasons of the year } \\
\hline & & Spring & Summer & Autumn & Winter \\
\hline 1 & 2 & 3 & 4 & 5 & 6 \\
\hline 1. N. constantini (Skv.) Skabitch. & & $\mathrm{r}$ & orm & $\mathrm{r}$ & \\
\hline 2. N cryptocephala Kuetz. & a & $\mathrm{sr}$ & om & o & $\mathrm{r}$ \\
\hline 3. N.cryptocephala var.veneta Grun. & a & or & or & mor & \\
\hline 4. N.lanceolata var.cymbula (Donk.) $\mathrm{Cl}$. & & & & rom & \\
\hline 5. N.lanceolata var.tenella A. S. & & s & s & $\mathrm{mrs}$ & \\
\hline 6. N.menisculus var.meniscus (Schum.) Hust. & & & $\mathrm{r}$ & $\mathrm{rm}$ & \\
\hline Total: & 2 & 4 & 5 & 6 & 1 \\
\hline
\end{tabular}

Table 1. Continued.

\begin{tabular}{|c|c|c|c|c|c|c|c|c|c|}
\hline \multirow{2}{*}{$\begin{array}{l}\text { Department name Bacillariophyta - } \\
\text { Diatomaceous algae } \\
\text { Class Pennatae, Order Raphinales, } \\
\text { Suborder Diraphineae, Family Naviculaceae } \\
\text { West., Genus Navicula Bory }\end{array}$} & \multicolumn{7}{|c|}{ Frequency of occurrence of algae in the basin } & \multicolumn{2}{|c|}{ New species for } \\
\hline & $\begin{array}{l}\text { Mountain } \\
\text { rivers, } \\
\text { Reservoir } \\
\end{array}$ & $\begin{array}{l}\text { Chirchik } \\
\text { river }\end{array}$ & $\begin{array}{l}\text { Right } \\
\text { irrigation } \\
\text { system } \\
\end{array}$ & $\begin{array}{l}\text { Left } \\
\text { irrigation } \\
\text { system } \\
\end{array}$ & $\begin{array}{l}\text { Fish } \\
\text { ponds }\end{array}$ & $\begin{array}{l}\text { Biological } \\
\text { ponds }\end{array}$ & $\begin{array}{l}\text { Rice } \\
\text { fields }\end{array}$ & $\begin{array}{l}\text { Chirchik } \\
\text { river basin }\end{array}$ & $\begin{array}{l}\text { Water } \\
\text { bodies of } \\
\text { Central Asia }\end{array}$ \\
\hline 1 & 7 & 8 & 9 & 10 & 11 & 12 & 13 & 14 & 15 \\
\hline 1. N. constantini (Skv.) Skabitch. & & & rom & & & & & rom & \\
\hline 2. N cryptocephala Kuetz. & $\mathrm{r}$ & $\mathrm{m}$ & mro & or & $\mathrm{r}$ & & o & & \\
\hline 4. N.lanceolata var.cymbula (Donk.) $\mathrm{Cl}$. & & мор & rom & & & & & orm & \\
\hline 5. N.lanceolata var.tenella A. S. & & & $\mathrm{mr}$ & & & & $\mathrm{s}$ & & \\
\hline 6. N.menisculus var.meniscus (Schum.) Hust. & & $\mathrm{r}$ & $\mathrm{rm}$ & & & & $\mathrm{r}$ & & \\
\hline Total: & 2 & 3 & 6 & 2 & 1 & 0 & 4 & 2 & 0 \\
\hline
\end{tabular}

Note: here and elsewhere, the frequency of occurrence is noted, which is equal to the following point system for hydrobiological research methods (1977): $\mathrm{s}-$ «single» or «singulary» or «units» $(1$ point $), \mathrm{r}$ - «rarely» $(3$ points $), \mathrm{o}-$ «often» $(5$ points $)$, vo - «very often» $(7$ points $), \mathrm{m}-\langle$ in mass» or «mass» $(9$ points $)$. aalpha-mesosaprobe.

96 species and varieties - less progressive algae, found "rarely", mostly "often" in the water bodies of the Chirchik river basin.

They are considered less resistant algae and less promising. The frequency of occurrence is equal to their 3 and 5 points. However, along with progressive and less progressive algae, regressing algae, such as Navicula contenta f.parallela Boye R., N.cryptocephala var.hancensis Skv., N.elongata Poretsky and others, are found on the verge of disappearing from the left bank irrigation systems. N.dicephala var.elginensis (Greg.) Grun was recorded in summer, autumn, and winter in the right bank irrigation system; in spring, summer and autumn - N.pelliculosa (Breb.) Hilse in the left bank irrigation system (table 2).

Regressing alga species of the genus Navicula Bory were recorded in 10 - in the left-bank, 5 - in the right-bank irrigation systems, 10 - in rice fields, 2 - in biological ponds. Among these, one species $N$. placentula (Ehr.) Grun. is first discovered in the water bodies of the Chirchik river basin. No regressing algae were found in mountain water bodies, reservoirs, fish ponds of the Chirchik river basin.

Studied the seasonality of regressing algae. Regressing algae of the genus Navicula Bory were recorded in water bodies of 2 species - in spring, 15 species - in summer, 9 species - in autumn and 2 species - in winter. They develop in a "single" amount or their frequency of occurrence is equal to "one point". This result proves that 20 species of algae from the genus Navicula Bory are on the verge of disappearing or regressing algae in the water bodies of the Chirchik River basin, and need protection.

\subsection{Main Influencing Factors on the Life of Algae}

Currently, climate change has caused the greenhouse effect. Those phenomena led to a reduction in the area of glaciers.

For example, over 40 years the position of the frontal line of the Kara-Batkak glacier has changed significantly.

The retreat of the frontal line of the glacier in the period from 1977 [9] to 2018 [27] averaged 375 meters [26], which corresponds to an average retreat rate of 5 to 8 meters per year. A certain influence on the glacier regime is exerted by the pollution of the glacier surface with various substances, the role of which in the intensification of the glacier melting is significant. For this reason, in most glaciers, the length and area of their open part gradually decrease over time. In addition, in most of the glacial zones of the Western Tien Shan [29], as well as in low areas of the Turkestan ridge, the seasonal snow line has gone beyond the ridge, as a result of which there is an increasing reduction in the areas of ice and firn. The range of distribution of glaciers in height is from 
3371 to $4411 \mathrm{~m}$ above sea level. The main part of the glacier area is concentrated in the $3500-3900 \mathrm{~m}$ above sea level $(83.4 \%)$. Reduction of ice and firn predicts low water supply in river basins of snow-water supply. This will lead to degradation of aquatic environments. From low water the photosynthetic layers of reservoirs become crowded and dense. There is not enough water to split the mass. Gas exchange with water and air is gradually disrupted. Eutrophication of water bodies is increasing. This is the first factor related to climate change [10].

Secondly: at present, the intensification of anthropogenic impact (industrial, municipal, agricultural wastewater and their emissions) affects the state of river basins. In connection, the degree of pollution of water chemicals is exceeded from the maximum permissible control (MPC) standards for the use of sanitary and fish farms [4]. For example, according to the data of Uzhydromet (1982, 2009, 2014) based on ionic anions and cations in the Bozsu channel, Levoberezhny Karasu channel, etc., as well as the Chirchik river, water salinity in the upper part is in the range of 180$286.1 \mathrm{mg} / \mathrm{l}$, the composition is bicarbonate-calcium $\left(\mathrm{HCO}_{3}\right.$ Ca) with a hardness of 1.85-2.27 mg-eq / 1 (soft).

Table 2. Regressing algae species of the genus Navicula Bory of water bodies of the Chirchik river basin.

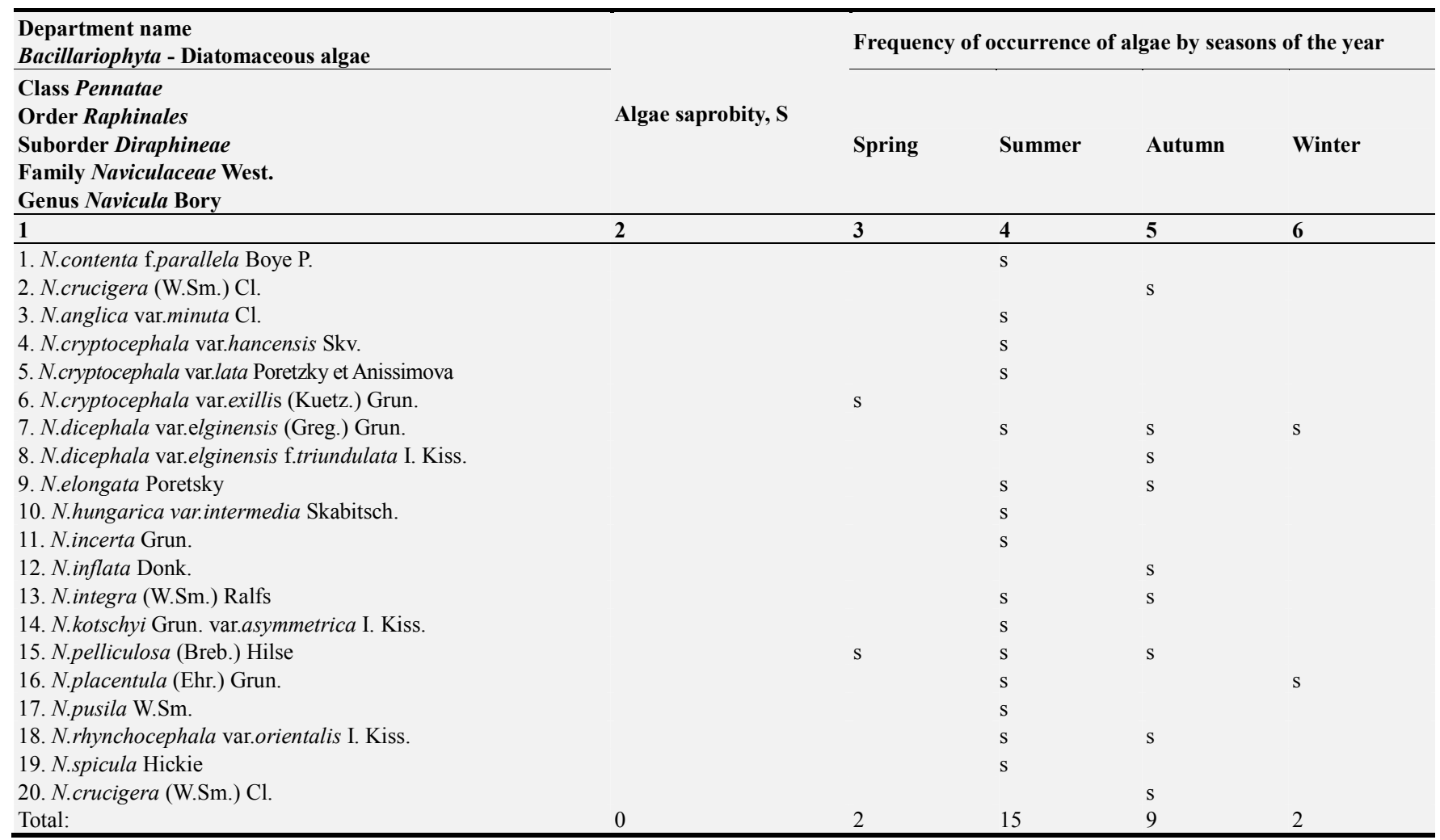

Table 2. Continued.

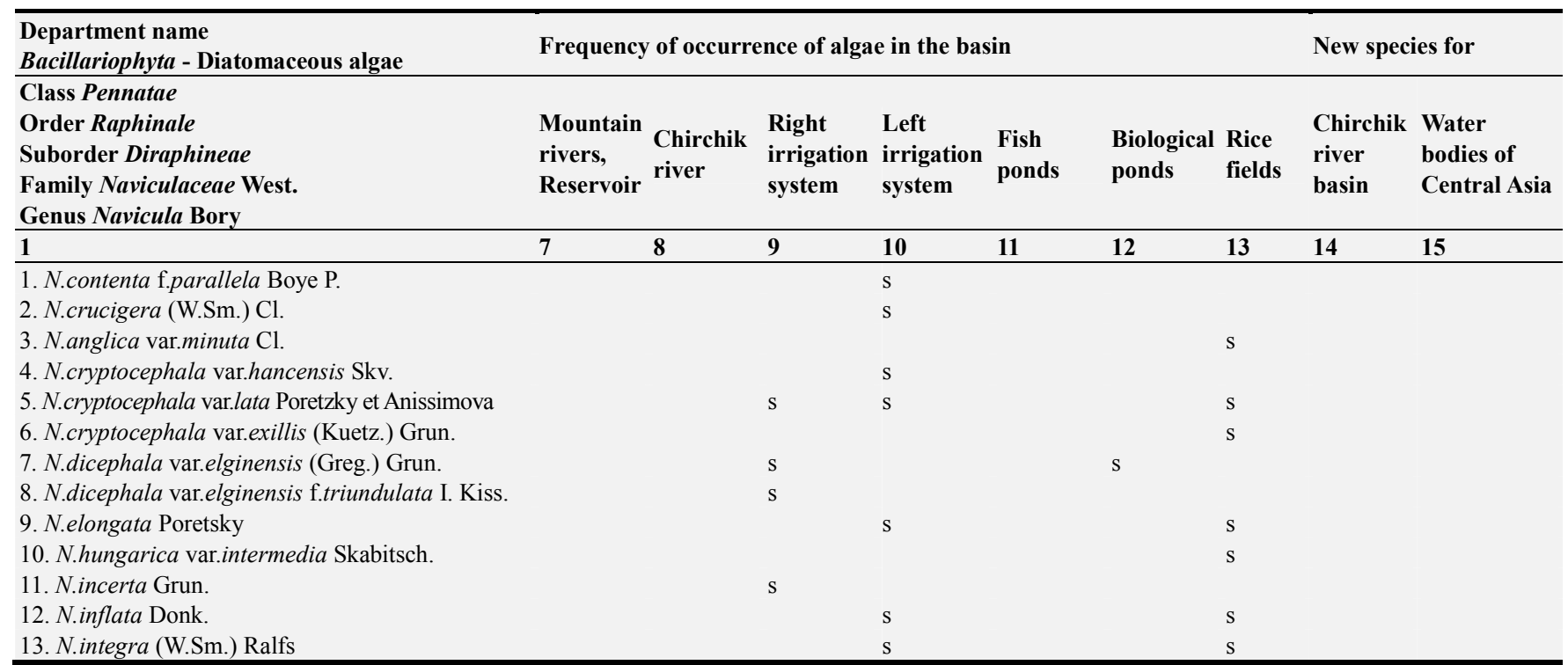




\begin{tabular}{|c|c|c|c|c|c|c|c|c|c|}
\hline $\begin{array}{l}\text { Department name } \\
\text { Bacillariophyta - Diatomaceous algae }\end{array}$ & Frequency & of occurr & nce of alga & $e$ in the bas & & & & New speci & ies for \\
\hline $\begin{array}{l}\text { Order Raphinale } \\
\text { Suborder Diraphineae } \\
\text { Family Naviculaceae West. } \\
\text { Genus Navicula Bory }\end{array}$ & $\begin{array}{l}\text { Mountain } \\
\text { rivers, } \\
\text { Reservoir }\end{array}$ & $\begin{array}{l}\text { Chirchik } \\
\text { river }\end{array}$ & $\begin{array}{l}\text { Right } \\
\text { irrigation } \\
\text { system }\end{array}$ & $\begin{array}{l}\text { Left } \\
\text { irrigation } \\
\text { system }\end{array}$ & $\begin{array}{l}\text { Fish } \\
\text { ponds }\end{array}$ & $\begin{array}{l}\text { Biological } \\
\text { ponds }\end{array}$ & $\begin{array}{l}\text { Rice } \\
\text { fields }\end{array}$ & $\begin{array}{l}\text { Chirchik } \\
\text { river } \\
\text { basin }\end{array}$ & $\begin{array}{l}\text { Water } \\
\text { bodies of } \\
\text { Central Asia }\end{array}$ \\
\hline 1 & 7 & 8 & 9 & 10 & 11 & 12 & 13 & 14 & 15 \\
\hline $\begin{array}{l}\text { 14. N.kotschyi Grun. var.asymmetrica I. Kiss. } \\
\text { 15. N.pelliculosa (Breb.) Hilse } \\
\text { 16. N.placentula (Ehr.) Grun. } \\
\text { 17. N.pusila W.Sm. } \\
\text { 18. N.rhynchocephala var.orientalis I. Kiss. } \\
\text { 19. N.spicula Hickie } \\
\text { 20. N.crucigera (W.Sm.) Cl. } \\
\text { Total: }\end{array}$ & 0 & 0 & $\mathrm{~s}$ & $\begin{array}{l}\mathrm{s} \\
\mathrm{s} \\
10\end{array}$ & 0 & $\mathrm{~s}$ & $\begin{array}{l}\mathrm{s} \\
\mathrm{s}\end{array}$ & $\mathrm{s}$ & 0 \\
\hline
\end{tabular}

In the middle (584.0-648.7 $\mathrm{mg} / \mathrm{l})$ and lower (1002.6-1500 $\mathrm{mg} / \mathrm{l})$ parts, especially in the estuary, the water salinity reaches $2890.3 \mathrm{mg} / \mathrm{l}$, the water composition is hydrocarbonate-sulphate-sodium calcium character $\left(\mathrm{HCO}_{3}-\right.$ $\mathrm{SO}_{4}-\mathrm{Na}-\mathrm{Ca}$ ), with a hardness of 6.22-11.0-22.06 mg-eq / 1 (very hard) [3]. Also slightly or noticeably exceeded from the norm - biogens: Ammonium salt $\mathrm{NH}_{4}^{+}$, nitrate ion $\mathrm{NO}_{3}{ }^{-}$, nitrite $\mathrm{NO}_{2}^{-}$, potassium $\mathrm{K}^{+}$, magnesium $\mathrm{Mg}^{2+}$, calcium $\mathrm{Ca}^{2+}$, copper $\mathrm{Cu}^{2+}$, nickel $\mathrm{Ni}^{2+}$, Zinc $\mathrm{Zn}^{2+}$, fluorine $\mathrm{F}^{-}$ion, cobalt $\mathrm{Co}^{2+}$, pesticides chlorine, sodium $\mathrm{Na}^{+}$, arsenic $\mathrm{As}^{3+}$, cyanides, chromium $\mathrm{Cr}^{6+}, \mathrm{Cr}^{3+}$, sulfate $\mathrm{SO}_{4}{ }^{2-}$ ion, chloride $\mathrm{Cl}^{-}$ion, oil products, phenols, vanadium $\mathrm{V}^{5-}$, molybdenum $\mathrm{Mo}^{2+}$, lead $\mathrm{Pb}^{2+}$, mercury $\mathrm{Hg}^{2+}$, magnesium $\mathrm{Mg}^{3+}$.

In some points, they have a detrimental effect on the life of aquatic organisms. In this regard, the species composition and quantity is reduced, becomes rare, even disappearing in the way. They are called regressive algae. There are such aquatic organisms, they do not react to this, on the contrary they thrive. They are called progressive aquatic organisms or algae of the investigated water bodies.

These two factors of climate change and anthropogenic load are the main influencing, threatening factors on the life of Navicul algae in the water bodies of the Chirchik river basin.

We recommend that 20 species of them be included in the next issue of the "Red Book on Plant Protection of Uzbekistan" and in the "Committee for Ecology and Nature Protection of the Republic of Uzbekistan". In the future, they should be included in the list in the protection of "protected plants and microorganisms of the Republic of Uzbekistan", in the section of microalgae microorganisms and periodically check with algologists their presence in the water bodies of the Chirchik river basin and eliminate the threatening factors, such as pollution of the water bodies of the Chirchik river basin with toxic substances.

From the genus Navicula Bory, in diatoms (Bacillariophyta), 122 species and varieties of algae were found in water bodies of the Chirchik River basin. Six species among algae are progressive, 96 are less progressive and 20 are regressive. An the future, progressive "full of life" will live, because they are more stable in different conditions, in water bodies they are always found "very often", "in mass" or the frequency of occurrence of 5,7,9 points; less progressive types of algae, they are intermediate, less resistant, their frequency of occurrence is always "often", sometimes "rare", the occurrence is equal to 5 and 3 points, but in the future there is "half life" and will live under great stress. Regressive species are always found "singly" or the frequency of occurrence is equal to one point. In the future, a threat to the safety of their lives is expected? maybe Not Live! (No Life!).

\section{Conclusions}

1) Studied the seasonality of progressive and regressing algae. In both cases, it is more varied in summer and autumn. Less in spring and winter.

2) Found for the first time new algae for water bodies of the Chirchik river basin among progressive and regressing ones.

3) Indicator-saprobic species of algae were noted among progressive algae.

4) Progressive algae are widespread: in the water bodies of the right-bank irrigation system there are only 6 species, in the left-bank ones - 2 , the Chirchik river - 3, rice fields - 4, mountain reservoirs, a reservoir - 2, fish ponds - 1, biological pond - not marked. They are resilient and promising algae

5) Less progressive, less resistant algae, there are 96 of them, the frequency of occurrence is "rare", "often and equal to 5, 3 points. And it is less promising.

6) Regressing algae are widespread: in water bodies of right-bank irrigation systems - 5, left-bank ones - 10, biological pond -2 , rice fields - 10. In the Chirchik river and mountain reservoirs, reservoir and fish ponds - not recorded. A regressive perspective is not guaranteed, a threat to the safety of life is expected.

\section{Recommendations}

Recommended to cultivate progressive microalgae for use in fish ponds, biological treatment plant and rice paddies, they are resistant to different habitats; We recommend regressing algae, in the amount of 20 species of them to be included in the next issue of the "Red Book on Plant 
Protection of Uzbekistan" of the Institute of Botany of the Academy of Sciences of the Republic of Uzbekistan, also in the "Committee of Ecology and Nature Protection of the Republic of Uzbekistan", in the future they should be included in the list in the protection of "protected plants and microorganisms of the Republic of Uzbekistan", in the section of microalgae microorganisms and periodically check with algologists their presence in the water bodies of the Chirchik river basin and take measures about the prospect of these algae, eliminate the threat factors, such as pollution with toxic substances that come with wastewater from the Chirchik river basin.

\section{Acknowledgements}

I would like to express my sincere gratitude to the staff of Science Publishing Group and the American Journal of BioScience (AJBIO) for the invitation and kind advice, also to the reviewers, for their timely advice and sincere help. Thanks for everything.

\section{References}

[1] Abdushukurov D. A., Abdusamadzoda D., Mamadaliev B., Nazarova O. D., Stotskiy D. F., Shaimuradov F. Water parameters in the main rivers of Tajikistan // J. Science, new technologies and innovations of Kyrgyzstan, Bishkek, No. 4, 2019. - S. 9-14.

[2] Alimjanova Kh. A. Algoflora of the Bozsu canal and its sanitary condition.: Author's abstract. dis.... Cand. biol. sciences. - Tashkent, 1991.- 23 p.

[3] Alimianova Kh. A. Regularities in the distribution of algae in the Chirchik river basin and their importance in determining the ecological and sanitary state of water bodies: Dis.... doct. biol. sciences. - Tashkent, 2005.- 233 p.

[4] Alimjanova Kh. A. Regularities in the distribution of algae in the Chirchik river basin and their importance in determining the ecological and sanitary state of water bodies. - Tashkent: Fan, 2007.- 265 p.

[5] Alimjanova Kh. A., Karimova B. K. Algoflora of the Akbuura River and its indicator saprobic species // Uzbek Biological Journal. - Tashkent, 1999. No. 2. - S. 39-42.

[6] Alimjanova Kh. A., Shayimkulova M. A. Algoflora of the Akbuura River and its importance in assessing water quality. Tashkent: Fan, 2008.- 126 p.

[7] Alimjanova Kh. A., Soatov G. T., Adylova M. A. Comparative study of the distribution of diatom saprobic indicator algae along the Kashkadaya River (Uzbekistan) // J. Science, new technologies and innovations of Kyrgyzstan, Bishkek, No. 4, 2019. - S. 23-27.

[8] Alimjanova Kh. A., Soatov G. T. Features of the distribution of indicator-saprobic algae along the course of the Kashkadarya River (Republic of Uzbekistan //j. Algologia. 2019, 29 (2): 185-200. Https://doi.org/10.15407/alg29.02.185

[9] Atlas of the Kirghiz SSR. T. 1. - M.: Ch. Department of Geodesy and Cartography under the Council of Ministers of the USSR, 19874.
[10] Veisov S. K., Khamraev G. O. The impact of climate change on the water resources of Turkmenistan // J. Science, new technologies and innovations of Kyrgyzstan, Bishkek, No. 4, 2019. - P. 31-35.

[11] Gollerbakh M. M., Polyansky V. I. Keys to freshwater algae of the USSR. Issue 1. Common part of freshwater algae and their study. - M.: Soviet science, 1951. - 200 p.

[12] Zabelina M. M., Kiselev I. A., Proshkina-Lavrenko A. I., Sheshukova V. S. Keys to freshwater algae of the USSR. Issue 4. Diatoms. - M.: Soviet science, 1951. - 619 p.

[13] Ismatova Z. A., Olimjonova X. O. Influence of environmental factors on the algal flora of the Sangzor River. - Tashkent: Navruz, 2014. - 64 p.

[14] Ismatova Z. A., Olimjonova X. O. Identifier of algae saprobiont indicators of the Sangzar River. - Tashkent: Navruz, 2017. $-155 \mathrm{p}$.

[15] Karimov I. A. Uzbekistan on the threshold of the XXI century: security threats, conditions and guarantees of progress. Tashkent: Uzbekistan, 1997. - pp. 105-128, 218-244, 320.

[16] Karimova B. K. Algoflora of water bodies in the south of Kyrgyzstan.: Author's abstract. dis.... doct. biol. sciences. Bishkek: KTNU, 1996. - 46 p.

[17] Karimova B. K. Algoflora of water bodies in the south of Kyrgyzstan. Bishkek: Technology, 2002. -214 p.

[18] Muzafarov A. M. Flora of algae in mountain reservoirs of Central Asia. - Tashkent: Academy of Sciences of the Uzbek SSR, 1958. - $380 \mathrm{p}$.

[19] Muzafarov A. M. Flora of algae in the Amu-Darya runoff. Tashkent: AN RUz, 1960. - 201 p.

[20] Muzafarov A. M. Flora of algae in water bodies of Central Asia. - Tashkent: Nauka, 1965. - 580 p.

[21] Muzafarov A. M. On the geographical distribution of algae. Tashkent: Fan, 1981. - 240 p.

[22] Olimjonova X. O., Yuldasheva M. P. Taxonomic list of algal flora and indicator species of the ShohimardonsoyMargilonsoy basin, their use. - Tashkent: Navruz, 2014. - 75 p.

[23] Toshpulatov Yu. Sh., Olimzhonova Kh. O. Flora of algae in the middle reaches of the Zarafshan River, its importance in assessing the ecological and sanitary state of water. - Tashkent: Navruz, 2015. -128 p.

[24] Tuzova T. V., Erokhin S. A., Zaginaev V. V., David Watkins. Non-equilibrium uranium as a natural radioactive indicator of the genesis of surface and underground waters in Central Asia // J. Science, new technologies and innovations of Kyrgyzstan, Bishkek, No. 4, 2019. - P. 85-91.

[25] Unified methods of water quality research. Part III. Methods for biological analysis of waters. 3rd ed. add. and perab. I Resp. for the release of Gubachek Z. - M.: SEV, 1977. - 185 p.

[26] Usubaliev R. A., Mamadalieva Z. E., Osmonov A. T. Analysis and assessment of the current situation in the basins of the transboundary rivers Kurkuroo, Padysha-Ata, Ak-Suu, Isfana: Current state of glacial systems // J. Science, new technologies and innovations of Kyrgyzstan, Bishkek, No. 4, 2019. - P. $92-$ 96.

[27] Physical geography of Kyrgyzstan B: Ilim - 2013. 
[28] Sheshukova V. S. Cameral processing. Diatom Analysis, Ed. Krishtofovich A. N. Book 1. L.: Gosgeolizdat, 1949. - pp. 8798.

[29] Ermenbaev B., Mamatkanov D. Satylkanov R., Popovnin V. V.
Changing approaches to calculating the mass balance of glaciers in the inner Tiang Shan // J. Science, new technologies and innovations of Kyrgyzstan, Bishkek, No. 4, 2019. - P. 116-121. 2. - C. 39-42. 